\title{
Vitamin D and its Association with the Severity and / or the Control of Asthma among Adult Iraqi Asthmatics
}

\author{
Haider Abdulhameed Alqaraghuli ${ }^{1}$, Hashim Mahdi Hashim ${ }^{2}$, \\ ${ }^{1}$ FICMS med FICMS Respiratory, College of Medicine, Al-Nahraine University/Iraq, \\ ${ }^{2} M R C P$, College of Medicine, al-Nahraine University/Iraq
}

\begin{abstract}
Background: asthma is one of the common chronic diseases with variable presentations and pathogenetic mechanisms. Vitamin D is thought to influence the expression as well as the severity, control and treatment responses in some asthmatic patients. Aim of study: to examine the possible association between asthma severity and level of control with vitamin D level in a sample of Iraqi adult asthmatics. Method: randomly selected 50 patients with asthma diagnosis were evaluated for medical factors of asthma harshness and control with measurement of 25-hydroxyvitamin D serum level (mean age \pm SD: $48.5 \pm 14.05$ years, $30 \%$ males, FEV1:1.44 $\pm 0.63 \mathrm{~L}, 60 \%$ severe, $60 \%$ poorly controlled). Results: most of asthmatic patients (96\%) were found to have vitamin D level of less than $30 \mathrm{ng} / \mathrm{ml}(17.66 \pm 7.06 \mathrm{ng} / \mathrm{ml})$ and this was related to severity of airway obstruction (mild: $28.71 \pm 5.52 \mathrm{ng} / \mathrm{ml}$, moderate: $19.9 \pm 4.56 \mathrm{ng} / \mathrm{ml}$, severe: $13.81 \pm 4.22 \mathrm{ng} / \mathrm{ml}$, $\mathrm{p}<0.001$ ) as well as control of asthma (controlled: $27.13 \pm 6.12 \mathrm{ng} / \mathrm{ml}$, partly controlled: $20.62 \pm 4.21 \mathrm{ng} / \mathrm{ml}$, uncontrolled: $17.66 \pm 7.06 \mathrm{ng} / \mathrm{ml}, \mathrm{p}<0.001)$. In addition, the $25(\mathrm{OH}) \mathrm{D}$ level was significantly associated with history of ER visits and hospitalizations. No significant association between the gender, age, BMI, the presence of allergic rhinitis and the status of vitamin D level. Conclusions: low levels of 25(OH)D were common in this sample of Iraqi adult asthmatics and was most prevalent and severe in those with severe and/ or uncontrolled asthma. This finding supports the hypothesis of possible vitamin D role in asthma.
\end{abstract}

Key words: vitamin D, severity and / or the control, asthma, Iraqi asthmatics.

\section{Introduction}

asthma is a common chronic illness with growing prevalence in many parts of the world for many years. More than 300 million persons from all ages, and different ethnics, grieve from asthma and its burden on patients, the families, and economy of the health authorities and is increasing internationally. It is defined by "a history of symptoms including wheeze, shortness of breath, chest tightness and cough that vary over time and in intensity, together with variable expiratory airflow limitation". (1)

It has been suggested that there is heterogeneity in asthma expression and phenotypes and these respond differently to treatment options which suggests different pathogenic mechanisms. In most asthmatics, i.e. the classical type, the symptoms are well controlled by beta 2 agonists and inhaled corticosteroids. However, some phenotypes of asthma do not exhibit similar response to corticosteroids and those patients are labelled as steroid - refractory and are challenging to manage clinically. $(2-6)$
Vitamin D affects the pathophysiology of asthma by effect on several mechanisms. It may help in maintaining the immune homeostasis especially the innate immunity by the direct stimulation of the expression of the gene responsible for the production of the antimicrobial peptide cathelicidin, which is known to be active against viruses, bacteria and fungi, and its deficiency may predispose to infections and consequent asthma exacerbations. ${ }^{(7)}$

In addition, vitamin $\mathrm{D}$ can reduce inflammation and smooth muscle proliferation by inhibiting the synthesis and release of cytokines related to the Th1 immune response and it may decrease the expression of TNF- $\alpha$ which lead to enhanced inflammatory response in asthmatics. In addition, it has been suggested that the level of $25(\mathrm{OH}) \mathrm{D}$ may facilitate steroid response in asthmatics. ${ }^{(8)}$. The purpose of study is to find any link between vitamin D level and the severity and / or the control of asthma in a sample of adult Iraqi asthmatics. 


\section{Method}

This is a cross sectional study of randomly selected 50 patients ( 35 females and 15 males) with asthma who regularly attend the respiratory medicine outpatient clinic at Al-Imamein Kadhimein Medical City. Patient interviewing and testing period was from the first of December 2014 till $31^{\text {st }}$ of December 2015. Inclusion criteria: confirmed asthma diagnosis, age 18 years and above

Exclusion criteria: presence of smoking history, use of supplemental vitamin $\mathrm{D}$, presence of co-morbid chronic condition like chronic renal failure, diabetes mellitus, heart failure and use of prolonged daily systemic steroids in the last year.

Asthma severity and control: the level of control and asthma severity were assessed via the simple questions suggested by Global Initiative for Asthma (GINA) ${ }^{1}$ by asking about the frequency of daytime symptoms, night symptoms, use of rescue inhalers and limitation of activity. Patients were grouped as well controlled, partly controlled and poorly controlled. Patients were grouped according to the forced expiratory volume in one second $\left(\mathrm{FEV}_{1}\right)$ percentage of predicted into mild intermittent/persistent ( $\geq 80 \%$ predicted), moderate persistent ( $\geq 60 \%$ but $<80 \%$ predicted) and severe $\left(<60 \%\right.$ predicted). ${ }^{(13)}$

Spirometry: according to the American Thoracic Society guidelines ${ }^{(14)}$, by a practiced operator using Masterscreen system (Jaeger Co., Höchberg, Germany) at the pulmonary function test laboratory in Al-Imamein Kadhimein Medical City. FEV $_{1}$ and forced vital capacity (FVC) were recorded. For those with $\mathrm{FEV}_{1}$ of less than $70 \%$ predicted, reversibility testing using nebulized salbutamol $2.5 \mathrm{mg}$ for 5 minutes and repeating the spirometry testing after 5 minutes was done. Reversibility was documented with both $200 \mathrm{ml}$ increase in FEV1 and $12 \%$ increase in FEV1.

Vit D level assessment: vitamin D level was determined using Vidas ${ }^{\circledR} 25 \mathrm{OH}$ Vitamin D Total test (bioMérieux SA, USA) according to the manufacturer recommendation. Levels of $<20 \mathrm{ng} / \mathrm{ml}$ considered deficiency, $20-29.9 \mathrm{ng} / \mathrm{ml}$ considered insufficiency and $\geq 30 \mathrm{ng} / \mathrm{ml}$ were considered as sufficient according to the previous recommendations. ${ }^{(14)}$

Other measurements: height and weight were recorded by a trained personnel during spirometry and the body mass index was calculated using the standard equation weight $(\mathrm{kg}) /$ height $(\mathrm{m})^{2}$.

Statistical Analysis : done by SPSS 22 , data were presented in simple measures of frequency, percentage, mean, standard deviation, and range (minimum-maximum values). Chi square test was used for categorical variables and Pearson's Correlation two tailed test was used for parametric variables. $P$ value was equal or less than 0.05 mean significant results.

\section{Results}

50 patients involved in the study, mean age was $48.5 \pm 14.05$ years (range $19-72)$. There were $35(70 \%)$ females and 15 males (35\%). Body mass index (BMI) was $30.72 \pm 7.86$ (range 15.79 - 53.69). The mean level of vitamin D was $(17.66 \pm 7.06) \mathrm{ng} / \mathrm{ml}$ and range from $8.1-39.80 \mathrm{ng} / \mathrm{ml}$. The FEV1 mean was $1.44 \pm 0.63 \mathrm{~L}$ with a range from 0.53 to $3.7 \mathrm{~L}$. as in table (1).

Table 1: Age, BMI, FEV1, FVC and $25(\mathrm{OH}) \mathrm{D}$ level in relation to gender (mean \pm SD)

\begin{tabular}{|l|l|l|}
\hline Variable & Female & Male \\
\hline Age (mean \pm SD) years & $48.17 \pm 14.56$ & $\begin{array}{l}49.27 \pm \\
14.83\end{array}$ \\
\hline BMI (mean \pm SD) & $32.76 \pm 7.90$ & $25.94 \pm 5.4$ \\
\hline FEV1 (mean \pm SD) L & $1.33 \pm 0.46$ & $1.69 \pm 0.88$ \\
\hline FVC (mean \pm SD) L & $2.07 \pm 1.72$ & $2.34 \pm 0.98$ \\
\hline $\begin{array}{l}25(O H) \text { level(mean } \pm \text { SD) } \\
\text { ng/ml }\end{array}$ & $17.01 \pm 6.75$ & $\begin{array}{l}19.16 \pm \\
7.77\end{array}$ \\
\hline
\end{tabular}

In this study, only 8 patients (16\%) had mild persistent asthma, and only 9 patients $(18 \%)$ had well controlled asthma. Figures 2 and 3 display the control and severity of asthma among this study sample respectively. Regarding treatments used for patients, 34 patients $(68 \%)$ were using beta agonist inhalers, $19(38 \%)$ were on inhaled corticosteroids (ICS) and $17(34 \%)$ on combination ICS and long acting beta agonist (LABA). There was no significant association between the treatment use and the level of $25(\mathrm{OH}) \mathrm{D}$. There is a significant positive correlation between the level of 25(OH)D and FEV1, $r(50)=0.772, p<0.001$. There was negative significant correlation between the level of vit $\mathrm{D}$ and the number of emergency visits, $r(50)$ $=-0.749, p<0.001$. Other correlations are shown in table 2 . 
Table 2 - Correlations of parametric variables with 25(OH)D level

\begin{tabular}{|l|l|l|}
\hline \multicolumn{2}{|l|}{ 25(OH)D correlations } & \multicolumn{2}{l|}{ Pearson's } \\
Variables & $\begin{array}{l}\text { Correlation ( r ) } \\
(\mathbf{p})\end{array}$ \\
\hline Age & -0.109 & 0.452 \\
\hline BMI & 0.195 & 0.174 \\
\hline FEV1 & 0.772 & $<0.001$ \\
\hline FVC & 0.224 & 0.118 \\
\hline FEV1/FVC & 0.557 & $<0.001$ \\
\hline Emergency Visits & -0.749 & $<0.001$ \\
\hline Hospitalizations & -0.465 & 0.001 \\
\hline
\end{tabular}

The level of asthma control was found to be significantly related to the severity of asthma $(p<0.001)$ with $60 \%(n=30)$ of patients having poorly controlled asthma, of whom $86.7 \%(n=26)$ having severe persistent asthma (Figure 1). In addition, the severity of asthma was significantly related to the status of vitamin $\mathrm{D}(\mathrm{p}<$ $0.001)$ with $81.8 \%(n=27)$ of patients with severe asthma having deficiency of $25(\mathrm{OH})($ level $<20 \mathrm{ng} / \mathrm{ml}$ ) (Figure $2)$. Moreover, the level of control was also significantly related to the status of vitamin D $(\mathrm{p}<0.001)$ with $96.7 \%(n=29)$ of poorly controlled asthmatics having deficiency of vitamin D (Figure 3).

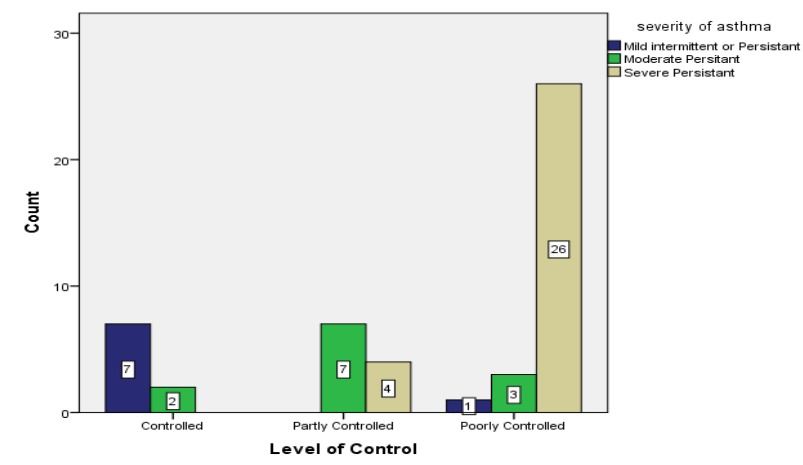

Figure 1: Level of asthma control and its severity

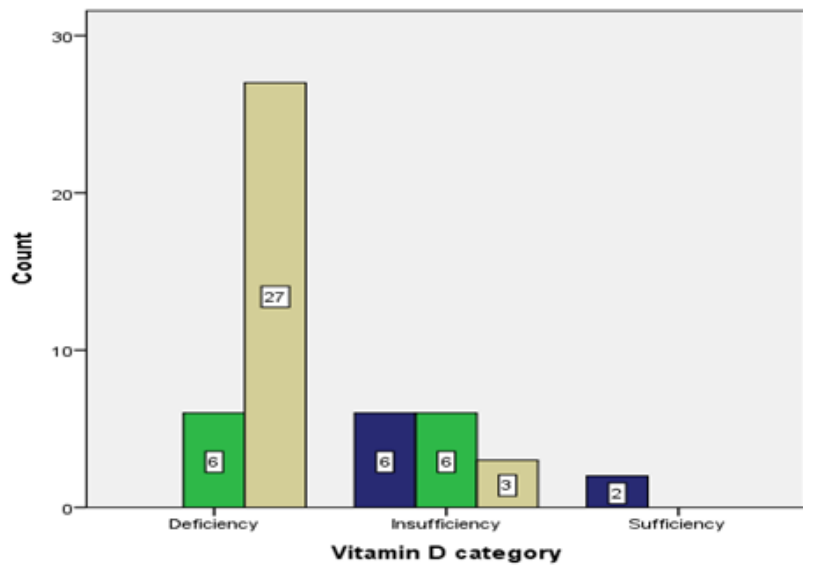

Figure 2: Level of asthma severity and Vitamin D status

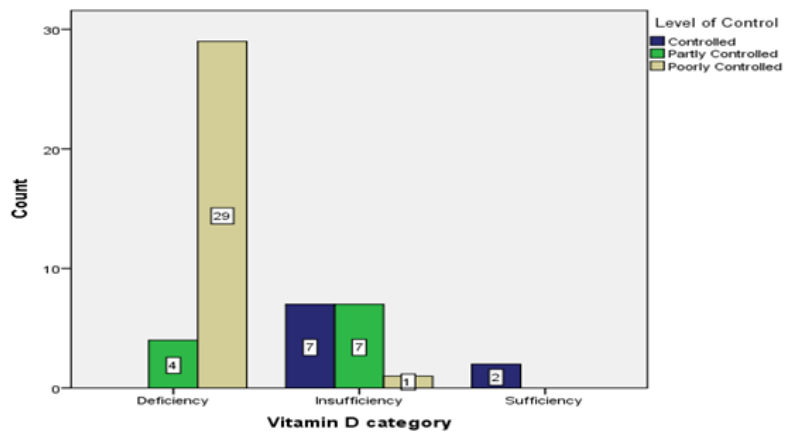

Figure 3: Level of asthma control and Vitamin D status

Mean and SD of levels of 25(OH)D, FEV1, FVC, FEV1/FVC according to the level of asthma severity and control are presented in tables 3 and 4.

Table 3 - means, standard deviations of $25(\mathrm{OH})$ D level, FEV1, FVC, FEV1/FVC and patient numbers in relation to the level of asthma control.

\begin{tabular}{|c|c|c|c|c|}
\hline $\begin{array}{l}\text { Asthma } \\
\text { Control } \\
\text { Level }\end{array}$ & $\begin{array}{l}25(\mathrm{OH}) \text { level } \\
(\mathrm{ng} / \mathrm{ml})\end{array}$ & FEV1(L) & FVC (L) & FEV1/FVC \\
\hline \multirow{2}{*}{$\begin{array}{l}\text { Controlled } \\
(\mathrm{n}=9)\end{array}$} & \multicolumn{4}{|l|}{ Mean \pm SD } \\
\hline & $27.13 \pm 6.12$ & $2.1 \pm 0.68$ & $2.51 \pm 1.01$ & $85.57 \pm 10.63$ \\
\hline \multirow{2}{*}{$\begin{array}{l}\text { Partly } \\
\text { controlled } \\
(\mathrm{n}=11)\end{array}$} & \multicolumn{4}{|l|}{ Mean \pm SD } \\
\hline & $20.62 \pm 4.21$ & $1.67 \pm 0.55$ & $2.12 \pm 0.59$ & $74.69 \pm 8.72$ \\
\hline \multirow{2}{*}{$\begin{array}{l}\text { Poorly } \\
\text { Controlled } \\
(\mathrm{n}=30)\end{array}$} & \multicolumn{4}{|l|}{ Mean \pm SD } \\
\hline & $17.66 \pm 7.06$ & $1.15 \pm 0.45$ & $2.02 \pm 1.87$ & $67.00 \pm 13.63$ \\
\hline
\end{tabular}


Table 4 - means, standard deviations of $25(\mathrm{OH})$ D level, FEV1, FVC, FEV1/FVC and patient numbers in relation to asthma severity

\begin{tabular}{|l|l|l|l|l|}
\hline Asthma Severity & $\mathbf{2 5 ( O H ) D ( n g / m l )}$ & FEV1 (L) & FVC (L) & FEV1/FVC \\
\hline Intermittent / Mild Persistent & $28.71 \pm 5.52$ & $2.2 \pm 0.68$ & $2.5 \pm 1.06$ & $89.72 \pm 9.77$ \\
\hline Moderate Persistent & $19.9 \pm 4.56$ & $1.7 \pm 0.54$ & $2.4 \pm 0.66$ & $72.97 \pm 7.87$ \\
\hline Severe Persistent & $13.81 \pm 4.22$ & $1.1 \pm 0.36$ & $1.9 \pm 1.85$ & $66.94 \pm 13.0$ \\
\hline
\end{tabular}

There was no significant association between the age, gender, BMI, the presence of allergic rhinitis and the status of vitamin D level.

\section{Discussion}

In this study, high prevalence of vitamin D deficiency and inadequacy among this sample of Iraqi adult asthmatics $(96 \%, \mathrm{n}=48)$. This high ratio is similar to that stated in Chinese (90\%) and Costa Rican (90\%) adult asthmatics but is higher than that recorded in German adult asthmatics (64\%). ${ }^{(12-14)}$ However, this percentage is much higher than that seen in childhood asthma reported in previous studies; $20 \%$ in Iranian, 28\% in Costa Rican, 38\% in Egyptian, and 44\% in Puerto Rican childhood asthmatics. ${ }^{(15-18)}$. These discrepancies between adults and children asthmatics may be related to behavioral variables seen in areas with plenty of sunny days as by avoiding sunlight, dress habits and racial difference in skin color. Importantly, in Iraq the cultural and religious background may play a role in limited sun exposure. Other variables for low vitamin D level like being overweight or female gender can also play a role but there was no significant association. In this study, the level of vitamin D was not associated with markers of allergy; namely the presence of allergic rhinitis used in our study. This lack of association of vitamin D level and markers of allergy has been described in some studies. $(9,12,13)$ However, such associations have been reported in other studies $(10,14,15,18)$ These contradicting results may be related to the different populations studied, the difference in allergen exposure between regions and the variability in outdoor exposure to sun in different parts of the world. These findings need cautious interpretation since the sample size is small and the other parameters of allergic response (like IgE level, sputum eosinophilia, allergen specific IgE antibodies, IL-4, and IL-5) have not been studied in this study. The major result of this study was the presence of significant correlation between the levels of vitamin D and the FEV1, FEV1 percent of predicted (as a marker of asthma severity), and FEV1/
FVC ratio (as a marker of airway obstruction), $\mathrm{p}<0.001$ for all parameters. This finding has been recorded in most of the studies in both adults and children. ${ }^{(11-19)}$. Moreover, vitamin D level was significantly associated with the level of asthma control, patients with higher level of vitamin D tend to have better asthma control $(27.13 \pm 6.12$ in controlled, $20.62 \pm 4.21$ in partly controlled and 17.66 \pm 7.06 in uncontrolled, $p<0.05$ ). This finding was also observed in a cross-sectional studies in Italian children and German adults. ${ }^{(11,14)}$

In this study, the risk of emergency department visits and hospitalizations were found to be significantly associated with vitamin D level, $\mathrm{p}<0.001$ for both. These findings are consistent with the results obtained

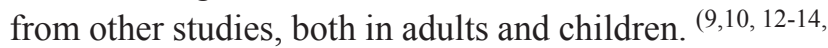
16-18)

However, a causal relationship between asthma and vitamin D deficiency cannot be established due to the sample size and cross-sectional project. In specific, the possibility of reverse causation cannot be eliminated as the patients with severe, poorly controlled asthma are more likely to be home bound with less exposure to sun and may be exposed to frequent steroid rescue courses that might have induced the deficiency state in vitamin D. Additional issue is the selection bias as there was unbalanced male to female ratio $(30 \%$ males vs. $70 \%$ females). However, comparable gender inequality in asthma have been recorded in previous studies conducted on Iraqi adult asthmatics. ${ }^{(19,20)}$ Also This study was conducted in a tertiary center and in a specialized respiratory unit, which may not reflect the overall population of asthmatics in Iraq. Additional limitation of this study is the absence of control group of well persons to regulate that the level of vitamin $\mathrm{D}$ has a solid association with asthma or this observation of low vitamin $\mathrm{D}$ level is just a coincidence. 


\section{Conclusion}

this study demonstrates that a low level of vit $\mathrm{D}$ is related with clinical parameters of poor asthma control plus severe asthma as predicted FEV1.

Ethical Clearance: The Research Ethical Committee at scientific research by ethical approval of both environmental and health and higher education and scientific research ministries in Iraq

Conflict of Interest: The authors declare that they have no conflict of interest.

Funding: Self-funding

\section{References}

1. Global strategy for asthma management and prevention 2015. Glob Initiat Asthma. 2015;149. Available online: www.ginasthma.org

2. Drazen JM. Asthma: the paradox of heterogeneity. J Allergy Clin Immunol 2012;129:1200-1201.

3. Wenzel SE. Asthma phenotypes: the evolution from clinical to molecular approaches. Nat Med 2012;18:716-725.

4. Wenzel S. Severe asthma: from characteristics to phenotypes to endotypes. Clin Exp Allergy 2012;42:650-658.

5. Pfeffer PE, Mann EH, Hornsby E et al. Vitamin D infleunces asthmatic pathology through its action on diverse immunological pathways. Ann Am Thorac Soc vol 11, supplement 5, 2014: $314-321$

6. Banerjee A, Damera G, Bhandare R, Gu S, LopezBoado Y, Panettieri R Jr, Tliba O Vitamin D and glucocorticoids differentially modulate chemokine expression in human airway smooth muscle cells. Br J Pharmacol. 2008 Sep; 155(1):84-92.

7. Herr C, Shaykhiev R, Bals R. The role of cathelicidin and defensins in pulmonary inflammatory diseases. Expert Opin Biol Ther 2007; 7:1449-61.

8. Sutherland ER, Goleva E, Jackson LP, Stevens AD, Leung DY: Vitamin D levels, lung function, and steroid response in adult asthma. Am J Respir Crit Care Med 2010; 181: 699-704.

9. Brehm JM, Schuemann B, Fuhlbrigge AL, Hollis BW, Strunk RC, Zeiger RS, Weiss ST, Litonjua AA. Serum vitamin D levels and severe asthma exacerbations in the Childhood Asthma Management Program study. J Allergy Clin
Immunol 2010;126:52-58e5.

10. Majak P, Olszowiec-Chlebna M, Smejda K, Stelmach I. Vitamin D supplementation in children may prevent asthma exacerbation triggered by acute respiratory infection. J Allergy Clin Immunol 2011;127:1294-1296.

11. Chinellato I, Piazza M, Sandri M, Peroni D, Piacentini G, Boner AL. Vitamin D serum levels and markers of asthma control in Italian children. $\mathrm{J}$ Pediatr 2011;158:437-441.

12. Li F, Peng M, Jiang L, Sun Q, Zhang K, Lian F et al. Vitamin D Deficiency Is Associated with Decreased Lung Function in Chinese Adults with Asthma. Respiration. 2011;81(6):469-475.

13. Montero-Arias F, Sedó-Mejía G, Ramos-Esquivel A. Vitamin D Insufficiency and Asthma Severity in Adults from Costa Rica. Allergy Asthma Immunol Res. 2013;5(5):283.

14. Korn S, Hübner M, Jung M, Blettner M, Buhl R. Severe and uncontrolled adult asthma is associated with vitamin D insufficiency and deficiency. Respiratory Research. 2013;14(1):25.

15. Alyasin S, Momen T, Kashef S, Alipour A, Amin R. The relationship between serum 25 hydroxy vitamin D levels and asthma in children. Allergy Asthma Immunol Res 2011;3:251-5.

16. Brehm JM, Celedón JC, Soto-Quiros ME, Avila L, Hunninghake GM, Forno E, Laskey D, Sylvia JS, Hollis BW, Weiss ST, Litonjua AA. Serum vitamin D levels and markers of severity of childhood asthma in Costa Rica. Am J Respir Crit Care Med 2009; 179:765-71.

17. Elnady HG, Hameed EA, Fouda E, Shaheed AA, Refaat E, Badawy E. SERUM VITAMIN D LEVELS AND MARKERS OF CHILDHOOD ASTHMA SEVERITY IN GREATER CAIRO. InINTENSIVE CARE MEDICINE 2011 Nov 1 (Vol. 37, pp. S355-S356). 233 SPRING ST, NEW YORK, NY 10013 USA: SPRINGER.

18. Brehm JM, Acosta-Pérez E, Klei L, Roeder K, Barmada M, Boutaoui N, Forno E, Kelly R, Paul K, Sylvia J, Litonjua AA, Cabana M, Alvarez M, Colón-Semidey A, Canino G, Celedón JC. Vitamin $\mathrm{D}$ insufficiency and severe asthma exacerbations in Puerto Rican children. Am J Respir Crit Care Med 2012;186:140-6.

19. Hashim M. Al-Kadhimi, Haider Noori Dawood. Obesity and asthma severity among adults presenting 
to the outpatient clinic. The Iraqi Postgraduate Medical Journal 2012; 11:205 - 210

20. Shakir M. Muhammad, Kassim M. Sultan, Mohammad Y. Abdulrazaq. Asthma in Adults: epidemiology, risk factors, and patterns of presentation: a cross sectional questionnaire based study in Baghdad Teaching Hospital. Karbala J. Med. 2012; 5:1255-1261. 